\title{
Dairy propionibacteria from milk or cheese diets remain viable and enhance propionic acid production in the mouse cecum
}

\author{
Adriana PÉREZ CHAIA ${ }^{\mathrm{a}, \mathrm{b} *}$, Gabriela ZÁRATE ${ }^{\mathrm{a}, \mathrm{b}}$ \\ a Centro de Referencia para Lactobacilos (CERELA-CONICET), Chacabuco 145, \\ 4000 - Tucumán, Argentina \\ b Facultad de Bioquímica, Química y Farmacia, Universidad Nacional de Tucumán, \\ Ayacucho 491, 4000 - Tucumán, Argentina
}

\begin{abstract}
The supply of carbohydrates is a growth-limiting factor for the intestinal microflora which ferments non-digested or incompletely digested carbohydrates, rendering short-chain fatty acids (SCFA) as major products. These organic acids are involved in a wide range of physiological functions. Therefore, it is of great interest to increase the SCFA intestinal production by using probiotic strains. The aim of this study was to assess in vitro and in vivo the contribution of four strains of propionibacteria to the production of SCFA and lactic acid in the mouse cecum, and to determine the viability and metabolic activity of propionibacteria in the cecum after feeding mice with a small Swiss-type cheese elaborated with $P$. acidipropionici CRL 1198. The bacterial count and total amount of SCFA, and the molar ratios of each acid and lactic acid concentration, were determined in the cecal content of mice after $7 \mathrm{~d}$ of feeding with milk containing different dairy propionibacteria (PAB). The same determinations were performed after in vitro lactose, sucrose or fructooligosaccharide fermentation in cecal homogenates inoculated with propionibacteria. Viability, adhesion to the intestinal mucosa and bacterial $\beta$-galactosidase activity were also compared in mice fed with milk or cheese containing $P$. acidipropionici CRL 1198 in a daily dose of $10^{9}$ bacteria. In our experiments, a milk and PAB feeding and lactose fermentation in the cecal content inoculated with $\mathrm{PAB}$ led to a higher production of propionic acid. In most cases propionibacteria increased propionic acid production at the expense of the butyric acid produced by the intestinal microflora. P. acidipropionici CRL 1198 maintained its adhesive property, viability and metabolic activity in the cecum of mice fed with a cheese diet. These results suggest that Swiss-type cheese could be used to deliver probiotic strains of propionibacteria to the human intestine.
\end{abstract}

Propionibacterium / survival / propionic acid / probiotic cheese

Résumé - Les bactéries propioniques laitières ingérées dans un régime avec du lait ou du fromage survivent et augmentent la production d'acide propionique dans le caecum des souris. L'apport de glucides est un facteur limitant de la croissance de la microflore bactérienne intestinale, qui fermente ces glucides partiellement ou non digérés, et produit principalement des acides gras à chaîne courte. Ces acides organiques sont impliqués dans de nombreuses fonctions physiologiques. C'est pourquoi beaucoup d'efforts ont été fournis afin d'améliorer la production intestinale d'acides gras à chaîne courte en utilisant des souches probiotiques. Nous avons évalué la contribution de quatre souches de bactéries propioniques, in vitro et in vivo, à la production d'acides gras à chaîne courte et d'acide lactique dans l'intestin de souris, ainsi que la viabilité et l'activité métabolique des

\footnotetext{
* Corresponding author: apchaia@cerela.org.ar
} 
bactéries propioniques dans le caecum de souris ayant ingéré un petit fromage à pâte pressée cuite ensemencé en $P$. acidipropionici CRL 1198. Les niveaux de la microflore intestinale, la quantité totale d'acides gras à chaîne courte, les proportions de chaque acide gras et la concentration en acide lactique ont été déterminées dans le caecum des souris après le $7^{\mathrm{e}}$ jour d'alimentation avec un régime expérimental contenant du lait et différentes souches de Propionibacterium. Les mêmes analyses étaient également effectuées lors de la fermentation in vitro de lactose, saccharose et des fructooligosaccharides (FOS) dans les homogénisats de contenu cecal ensemencé en bactéries propioniques. La viabilité, l'adhésion à la muqueuse intestinale et l'activité de la $\beta$-galactosidase bactérienne ont également été comparées chez des souris ayant ingéré un régime expérimental contenant du lait ou du fromage et $P$. acidipropionici CRL 1198 à une dose journalière de $10^{9}$ bactéries. L'alimentation des souris avec du lait contenant des bactéries propioniques et la fermentation du lactose dans le contenu cecal ensemencé avec les mêmes souches aboutissait à une production plus élevée d'acide propionique. Dans la plupart des cas, les bactéries propioniques augmentaient la production d'acide propionique au détriment de l'acide butyrique produit par la microflore intestinale. P. acidipropionici CRL 1198 conservait ses propriétés d'adhésion, sa viabilité et son activité métabolique dans le caecum de souris ayant ingéré le fromage contenant cette souche. Ces résultats laissent penser que le fromage à pâte pressée cuite pourra être utilisé comme vecteur d'apport de Propionibacterium dans l'intestin chez l'homme.

\section{Propionibacterium / survie / acide propionique / fromage probiotique}

\section{INTRODUCTION}

The large intestine of adult humans harbors a complex microbiota in an intimate interaction with the host. Different substrates such as dietary residues, mucus and lysis products from both epithelial and bacterial cells [25] are available for the nutrition of intestinal bacteria. However, gut bacteria depend on the supply of dietary carbohydrates that have escaped digestion in the upper gastrointestinal tract to obtain energy for growth and maintenance of cellular functions. The supply of carbohydrates is an important factor limiting bacterial growth in the colon, and bacteria able to transform the available substrates most rapidly occur in the greatest numbers [13]. Therefore, they have a great incidence on the development of the different bacterial species and their metabolic activity.

Fermentation is the main process whereby strict and facultative anaerobes of the intestinal microflora break down dietary and endogenous substrates in order to obtain energy for growth and maintenance of cellular functions. This anaerobic redox process generates ATP via substrate-level phosphorylation coupled to the partial oxidation of the substrate through pathways with different metabolic intermediates. The pathways of fermentation of most bacterial species are complex, usually involving several organic intermediates as electron donors and electron acceptors. Each bacterial genus transforms the intermediate metabolites into products of different type and molar yield $[27,34]$ by the reductive steps of the fermentation process.

In a mixed population like the intestinal microflora, carbohydrates are broken down cooperatively. The fermentation products of some species are substrates for fermentation or incorporated as intermediate metabolites into the metabolic pathways of other species, resulting in sequentially-fermented substrates. Lactate, ethanol, pyruvate and succinate produced by some bacteria are utilized by species other than their producers, mainly generating short-chain fatty acids in the intestinal content. Therefore, the major products of sugar catabolism are acetate, propionate and butyrate, which represent 85-95\% of total SCFA in all the colon regions $[6,7]$. Although SCFA come mainly from the breakdown of carbohydrates, protein, peptide and glycoprotein precursors are also substrates for some anaerobic microorganisms able to ferment amino acids.

These organic acids are involved in a wide range of physiological functions such as the transport of electrolytes and water, growth and differentiation of colonic mucosa, apoptosis of aged or altered colonocytes, metabolism of lipids in the liver and energy 
supply for different tissues [6]. Many environmental, dietary, microbial and hostrelated factors regulate SCFA formation by intestinal bacteria and determine the amounts and types of acids produced in healthy individuals.

Several attempts have been made to increase SCFA production of colonic fermentation by means of Lactobacillus and Bifidobacterium probiotic strains [19, 20]. Among dairy bacteria, propionibacteria seem to be better candidates for improving SCFA production within the intestine, since they themselves are propionic and acetic acid producers.

In the last few years, our laboratory has evaluated the ability of dairy propionibacteria to survive in the adverse conditions of the gastrointestinal tract [37,39], adhere to the intestinal mucosa [38] and contribute to the production of SCFA with impacts on the host's health $[29,30]$. Some factors involved in the adhesion and how gastrointestinal digestion affects this property were also studied [40].

The objective of the present work was to evaluate in vivo and in vitro the production of SCFA in the intestinal environment by using a murine model and different adhesive propionibacteria strains able to survive gastrointestinal digestion. The persistence of one of the strains and its contribution to the $\beta$-galactosidase activity in the intestinal environment after feeding mice with an experimental cheese manufactured in our laboratory was also noted.

\section{MATERIALS AND METHODS}

\subsection{Microorganisms and culture conditions}

The microorganisms used in this study were Propionibacterium freudenreichii CRL 757 and F3, and Propionibacterium acidipropionici CRL 1198 and Q4 (CRL: Centro de Referencia para Lactobacilos, CERELA, Tucumán, Argentina). Strains F3 and Q4 were obtained from the Laboratorio de Ecofisiología Tecnológica-CERELA.
All strains were stored at $-20{ }^{\circ} \mathrm{C}$ in $10 \%$ (w/ v) reconstituted non-fat milk (NFM) containing $0.5 \%$ yeast extract. Before use, they were activated by three successive transfers for $24 \mathrm{~h}$ at $37^{\circ} \mathrm{C}$ in BHI broth sterilized at $121{ }^{\circ} \mathrm{C}$ for $15 \mathrm{~min}$. In some experiments, strains were activated in YE lactose broth [39] with the following composition: $1 \%$ Tryptone, $1 \%$ yeast extract, $0.05 \%$ cysteine, $0.05 \%$ Tween $80,0.025 \% \mathrm{~K}_{2} \mathrm{HPO}_{4}$ and $0.005 \% \mathrm{MnSO}_{4}$. The medium was adjusted to $\mathrm{pH} 6.8$, sterilized at $121^{\circ} \mathrm{C}$ for $15 \mathrm{~min}$ and then supplemented with $1 \%$ filter-sterilized lactose.

\subsection{Animals and feeding procedures for in vivo studies}

The animals used in our studies were 42-d-old BALB/c male albino mice. A first trial was performed with 6 treatment groups, each containing five animals. They were housed in cages and received a solid conventional balanced diet (CARGILL, Molinos, Entre Ríos, Argentina) with or without (controls) different propionibacteria strains delivered in their drink.

Twenty-four-hour cultures of each strain of propionibacteria grown in YE with lactose broth were harvested by centrifugation $\left(3000 \mathrm{~g} ; 4^{\circ} \mathrm{C}\right)$, washed in sterile saline solution and suspended in sterile $10 \%(\mathrm{w} / \mathrm{v})$ NFM (non-fat milk) to the desired concentration (ca. $5 \times 10^{8}$ bacteria per $\mathrm{mL}$ ). Dairy propionibacteria, provided in the drinking bottles of different test groups, represented a consumption of ca. $10^{9}$ bacteria per day. Control groups received sterile NFM or water.

The mice received the diet and their assigned drink ad libitum for $7 \mathrm{~d}$ and were sacrificed at the end of the treatment after an overnight period with water only. The cecum was bound at both ends with sterile thread, cut $2 \mathrm{~cm}$ from each tie and introduced into an anaerobic glove box (Anaerobic System model 1024, Forma Scientific, Marietta, USA) with an atmosphere of $85 \%$ $\mathrm{N}_{2}, 5 \% \mathrm{CO}_{2}$ and $10 \% \mathrm{H}_{2}$. The cecal content was removed, weighed and diluted in prereduced sterile saline solution $(0.9 \% \mathrm{w} / \mathrm{v}$ $\mathrm{NaCl})$ to adequate volume. Aliquots of the cecal suspensions obtained were serially 
diluted and counts of the main intestinal populations were determined. The suspensions were finally centrifuged $(1000 \mathrm{~g}$; $10 \mathrm{~min} ; 4{ }^{\circ} \mathrm{C}$ ) and the supernatants were frozen for further analysis.

In another trial, mice were randomly divided into 4 treatment groups, each containing five animals. They received the solid conventional balanced diet and water, NFM or NFM with $P$. acidipropionici CRL1198 in their drinking bottles (a dose of ca. $10^{9}$ bacteria per day). Another group of animals was given a conventional solid diet supplemented with an experimental Swiss-type cheese and water in their drinking bottles.

Small, 500-g experimental Swiss-type cheeses were prepared with cultures in the exponential phase of S. thermophilus LEC1, L. bulgaricus LEC2, L. helveticus CC1, $L$. casei QC and P. acidipropionici CRL1198, all of them from CERELA laboratories. The cheese was made following a technology for this variety [22] adapted to a small volume and ripened for $21 \mathrm{~d}$ at $12{ }^{\circ} \mathrm{C}$ and $28 \mathrm{~d}$ at $25{ }^{\circ} \mathrm{C}$. The daily cheese ration adjusted for mice feeding provided $10^{9}$ propionibacteria per day.

After $7 \mathrm{~d}$ of feeding with their assigned diet, the mice received only water for an overnight period and were sacrificed the next morning. The cecal contents and tissues, placed in an anaerobic glove box [29], were used to determine the number of propionibacteria and $\beta$-galactosidase activity.

\subsection{Procedures for in vitro studies}

For in vitro studies, nine mice were sacrificed by cervical dislocation and the cecal contents were obtained as described above. They were weighed and diluted in prereduced sterile saline solution $(0.9 \% \mathrm{w} / \mathrm{v}$ $\mathrm{NaCl})$ to give $10 \%(\mathrm{w} / \mathrm{v})$ suspensions. Twenty-four-hour cultures of each strain of propionibacteria grown in lactose broth were harvested by centrifugation $(3000 \mathrm{~g}$; $4{ }^{\circ} \mathrm{C}$ ), washed in pre-reduced sterile saline solution and suspended in one-tenth of the original volume of the culture. Cecal suspensions were inoculated with the different strains of propionibacteria to the desired concentration $\left(10^{9}\right.$ bacteria per $\left.\mathrm{mL}\right)$ and supplemented with $25 \mathrm{~g} \cdot \mathrm{L}^{-1}$ sterile lactose. Control suspensions were prepared without propionibacteria, or without lactose and propionibacteria. After $12 \mathrm{~h}$ of incubation at $37{ }^{\circ} \mathrm{C}$ in the anaerobic globe box, each suspension was centrifuged $(10000 \mathrm{~g}$; $10 \mathrm{~min} ; 4^{\circ} \mathrm{C}$ ) and the correspondent supernatants were stored at $-20{ }^{\circ} \mathrm{C}$ for further analysis.

In a similar experiment, mice cecal homogenates obtained as described above were supplemented with sterile water, sucrose or FOS $\left(10 \mathrm{~g} \cdot \mathrm{L}^{-1}\right)$ and half of the volume of each sample was inoculated with P. acidipropionici CRL1198. This strain was grown in BHI broth and harvested after $24 \mathrm{~h}$ of incubation at $37^{\circ} \mathrm{C}$. A suspension of one-tenth of the original volume of the culture in pre-reduced sterile saline solution was used to inoculate cecal homogenates up to $10^{9}$ bacteria per gram of wet weight. Homogenates were then incubated for $12 \mathrm{~h}$ at $37^{\circ} \mathrm{C}$ in an anaerobic environment. They were centrifuged $(10000 \mathrm{~g}$; $10 \mathrm{~min} ; 4^{\circ} \mathrm{C}$ ) and the correspondent supernatants stored at $-20^{\circ} \mathrm{C}$ for further analysis.

\subsection{SCFA and lactose measurements}

Lactose concentration was measured using a spectrophotometric lactose-galactose method (Boehringer, Mannheim, Germany) [20]. The samples were diluted 1:10 to 1:20 with redistilled water, acidified with trichloroacetic acid $\left(250 \mathrm{~g} \cdot \mathrm{L}^{-1}\right)$ to precipitate protein, centrifuged for $30 \mathrm{~min}(3000 \mathrm{~g}$; $4{ }^{\circ} \mathrm{C}$ ), and neutralized with $1 \mathrm{~mol} \cdot \mathrm{L}^{-1} \mathrm{NaOH}$ before analysis.

Short-chain fatty acids and lactate were determined by HPLC, using a $300 \times 7.8 \mathrm{~mm}$ Rezex ROA-organic acids column (Phenomenex, Torrance, USA) operated at $55^{\circ} \mathrm{C}$ with $\mathrm{H}_{2} \mathrm{SO}_{4} 0.01 \mathrm{~mol} \cdot \mathrm{L}^{-1}$ as the mobile phase. Samples were acidified with $\mathrm{H}_{2} \mathrm{SO}_{4}$ $0.01 \mathrm{~mol} \cdot \mathrm{L}^{-1}$, centrifuged for $30 \mathrm{~min}(3000 \mathrm{~g}$; $\left.4{ }^{\circ} \mathrm{C}\right)$ and then filtered $(0.2-\mu$ membrane, Millipore, MA, USA). The retention times for individual fatty acids were determined by injecting each standard separately on the column. 


\subsection{Bacteriological analysis}

Serial ten-fold dilutions of the cecal homogenates were made in pre-reduced $0.1 \%(\mathrm{w} / \mathrm{v})$ peptone in the anaerobic glove box. They were plated in triplicate onto different selective and non-selective media as follows: Brain Heart Infusion blood agar (BHI, Difco, BD Argentina SRL, Buenos Aires, Argentina) supplemented with vitamin $\mathrm{K}$ and hemin (total bacteria); phenylethanol agar (Difco) (total Gram-positive bacteria) and Azide blood agar (Oxoid, NY, USA) (mainly streptococci); all of them incubated aerobically and anaerobically at $37^{\circ} \mathrm{C}$ for $96 \mathrm{~h}$. Slantez-Bartley agar (Oxoid) aerobically incubated at $37{ }^{\circ} \mathrm{C}$ for $3 \mathrm{~d}$ and violet red-bile-glucose agar (Oxoid) aerobically incubated at $37^{\circ} \mathrm{C}$ for $24 \mathrm{~h}$ were used for counts of Enterococcus and Enterobacteriaceae, respectively. Rogosa agar (Difco) containing glacial acetic acid $\left(1.32 \mathrm{~mL} \cdot \mathrm{L}^{-1}\right)$, ECOTEC agar [4] and Columbia modified agar medium [3] anaerobically incubated at $37^{\circ} \mathrm{C}$ for $5 \mathrm{~d}$ were used for counts of Lactobacillus; Propionibacterium and Bifidobacterium, respectively.

Confirmation of bacterial genera from selective media was based on morphology, Gram stain, fermentation product formation and biochemical tests. Further identification of individual species of microorganisms was not undertaken.

\subsection{Determination of $\beta$-galactosidase activity}

The $\beta$-galactosidase (EC 3.2.1.23) activity in cecal homogenates was determined by measuring the hydrolysis rate of the synthetic substrate o-nitrophenyl- $\beta$-D-galactopyranoside (ONPG, N-1127, Sigma) in $50 \mathrm{mmol} \cdot \mathrm{L}^{-1} \mathrm{KH}_{2} \mathrm{PO}_{4}-\mathrm{Na}_{2} \mathrm{HPO}_{4}$ buffer, $\mathrm{pH}$ 7.0. The enzymatic reaction mixture consisted of $200 \mu \mathrm{L}$ of each homogenate, $0.836 \mathrm{mmol} \cdot \mathrm{L}^{-1} \mathrm{ONPG}$ and $50 \mathrm{mmol} \cdot \mathrm{L}^{-1}$ phosphate buffer, $\mathrm{pH} 7$, in a final volume of $1 \mathrm{~mL}$. The mixtures were incubated for $15 \mathrm{~min}$ at $37^{\circ} \mathrm{C}$ and the reactions stopped with $800 \mu \mathrm{L}$ of $0.5 \mathrm{~mol} \cdot \mathrm{L}^{-1} \mathrm{Na}_{2} \mathrm{CO}_{3}$ [39]. Reaction mixtures were clarified by centrifugation $(10000 \mathrm{~g} ; 10 \mathrm{~min})$ before determining the absorbance at $440 \mathrm{~nm}$. The enzymatic activity was expressed as nanomols of o-nitrophenol (ONP) liberated per minute per gram of cecal content.

\subsection{Statistical analysis}

The results are the average of the data obtained. Significant differences between means were determined by Tukey's test $(P<0.05)$ after analysis of variance (ANOVA) with the Minitab Statistic Program, release 12 for Windows.

\section{RESULTS}

\subsection{In vivo fermentation}

The objective of the first experiment was to determine the actual concentration of SCFA in the cecal content of mice while feeding on milk and dairy propionibacteria (PAB). Two control groups were included, with water or milk in their drinking bottles. Water control provided the basal value of SCFA in the intestinal environment of the mice while milk control was included to assess the contribution of the normal flora to acid production during milk consumption.

Figure 1 shows SCFA and lactic acid production in both control groups. There was a significant increase in the total amount of SCFA determined after $7 \mathrm{~d}$ of a daily consumption of milk, but not in the individual acid species. The molar ratios of each acid (Tab. I), as determined for both control groups, showed a slight reduction in acetic and propionic acid, and an increase in butyric acid in the milk-feeding group, indicating a higher contribution of butyric acid producer flora to the intestinal fermentation. The relative amount of lactic acid, expressed as mmol per $100 \mathrm{mmol}$ of total acids, showed a significant reduction in that group.

Figure 1 also shows intestinal SCFA and lactic acid production in the test groups fed with the diet of milk containing two different strains of $P$. acidipropionici. There were no significant differences with the milk-fed control in the total amount of SCFA produced. However, we noticed moderate increases in propionic acid, remarkable 
Table I. Relative amounts of acetic, propionic, butyric and lactic acids in the cecal content of mice from different feeding groups ${ }^{\mathrm{a}}$ and in mice cecal homogenates after lactose fermentation ${ }^{\mathrm{b}}$.

\begin{tabular}{|c|c|c|c|}
\hline Studies & Sample & $\begin{array}{c}\text { Ratio } \\
\mathrm{A}: \mathrm{P}: \mathrm{B}^{\mathrm{c}}\end{array}$ & $\begin{array}{l}\text { Lactate } \\
\qquad(\%)^{\mathrm{d}}\end{array}$ \\
\hline \multicolumn{4}{|l|}{ In vivo ${ }^{a}$} \\
\hline & Water (basal) & $58: 22: 20$ & 9.0 \\
\hline & Milk & $57: 20: 23$ & 5.0 \\
\hline & Milk + P. acidipropionici CRL1198 & $57: 24^{*}: 19^{*}$ & $19.8 *$ \\
\hline & Milk + P. acidipropionici $\mathrm{Q} 4$ & $61: 27 *: 12 *$ & $21.1 *$ \\
\hline & Milk + P. freudenreichii CRL757 & $57: 27^{*}: 16^{*}$ & $15.3 *$ \\
\hline & Milk $+P$. freudenreichii $\mathrm{F} 3$ & $57: 30 *: 14^{*}$ & 9.3 \\
\hline \multicolumn{4}{|l|}{ In vitrob } \\
\hline & Water control & $54: 20: 26^{+}$ & 5.0 \\
\hline & Lactose control & $54: 18: 28^{+}$ & $19.6^{+}$ \\
\hline & Lactose $+P$. acidipropionici CRL1198 & $50 *: 29 *: 21$ & 16.4 \\
\hline & Lactose + P. acidipropionici Q4 & $43 *: 34 *: 23$ & 16.9 \\
\hline & Lactose $+P$. freudenreichii CRL757 & $49 *: 31 *: 20$ & $7.3^{*}$ \\
\hline & Lactose $+P$. freudenreichii $\mathrm{F} 3$ & $45^{*}: 32 *: 22$ & $4.8 *$ \\
\hline
\end{tabular}

a The different groups were fed with a solid conventional diet and drank water, milk or milk with propionibacteria ( $10^{9}$ bacteria per day) for $7 \mathrm{~d}$.

${ }^{\mathrm{b}}$ Mice cecal homogenates were supplemented with sterile lactose, inoculated or not with different propionibacteria $\left(10^{9} \mathrm{cfu} \cdot \mathrm{g}^{-1}\right)$ and incubated for $12 \mathrm{~h}$ at $37^{\circ} \mathrm{C}$.

c A, acetate; P, propionate; B, butyrate (Mean value of $\%$ of total SCFA). Relative amounts of each SCFA and lactate were calculated and statistically analyzed (Materials and Methods). A plus symbol in control samples indicates significant differences $(P<0.05)$ compared with the basal value. Asterisks indicate significant differences in PAB-supplemented samples compared with their correspondent control samples.

${ }^{d}$ Mean value of $\%$ of total acids.

increases in lactic acid and reductions in butyric acid production (Tab. I).

In the presence of $P$. freudenreichii, we observed results similar to those of $P$. acidipropionici (Fig. 2). However, a lower amount of lactic acid and a higher amount of propionic acid were determined in the test groups fed with milk containing $P$. freudenreichii $\mathrm{F} 3$ and $P$. freudenreichii CRL757, probably due to the preferential consumption of lactate by this species [24].

Counts of the overall flora were at a slightly higher number after a daily con- sumption of milk for $7 \mathrm{~d}$ (Fig. 3) in the milkfed control and in all the test groups, compared with the water-drinking group. Enterobacteria remarkably increased in the milk-fed control compared with the water control group, but the presence of PAB prevented their proliferation in all test groups. Two strains of PAB also had an inhibitory effect on the growth of enterococci. However, the dominant bacterial groups of the intestinal microflora responsible for the production of SCFA were not modified by the presence of $\mathrm{PAB}$. 


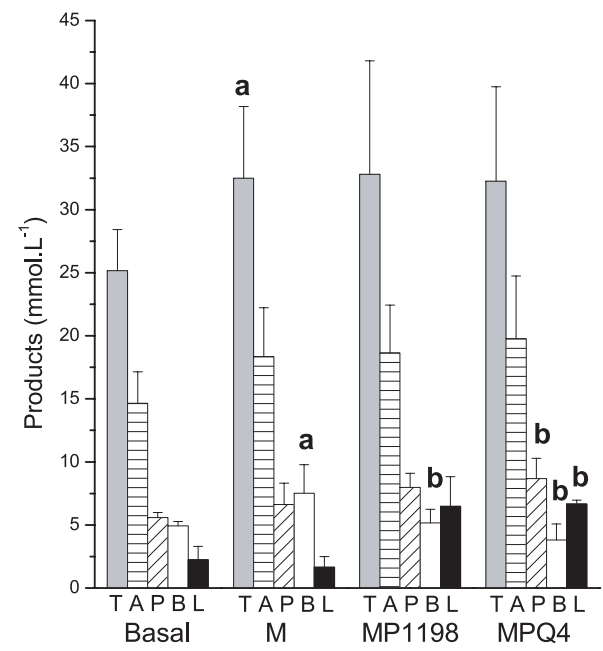

Figure 1. SCFA and lactic acid in the cecal content of mice on the 7 th day of feeding with experimental diets. Diets are indicated as follows: Basal, water control; M, non-fat milk; MP1198, non-fat milk containing P. acidipropionici CRL1198; MPQ4, non-fat milk containing $P$. acidipropionici $\mathrm{Q} 4$. Significant differences between controls $(P<0.05)$ are indicated with the character $\mathbf{a}$; significant differences between treatments and $\mathrm{M}$ group $(P<0.05)$ are indicated with the character b. Columns: grey, total SCFA (T); horizontal lines, acetic acid (A); slant lines, propionic acid (P); white, butyric acid (B); black, lactic acid (L).

\subsection{In vitro fermentation}

In order to understand the contribution of PAB to the intestinal fermentation when a load of carbohydrates reaches the ceca, we evaluated the SCFA production in mice cecal homogenates inoculated with $\mathrm{PAB}$ and supplemented with $25 \mathrm{~g} \cdot \mathrm{L}^{-1}$ of sterile lactose after $12 \mathrm{~h}$ of incubation at $37{ }^{\circ} \mathrm{C}$.

As shown in Figure 4, the control homogenate to which only lactose was added showed a ten- to twenty-fold increase in SCFA and lactic acid production. The relative amounts of SCFA and lactate showed differences related to the basal value. While acetic and propionic acids' molar ratios diminished, butyric and lactic acids' relative amounts increased (Tab. I). However, when the lactose control sample

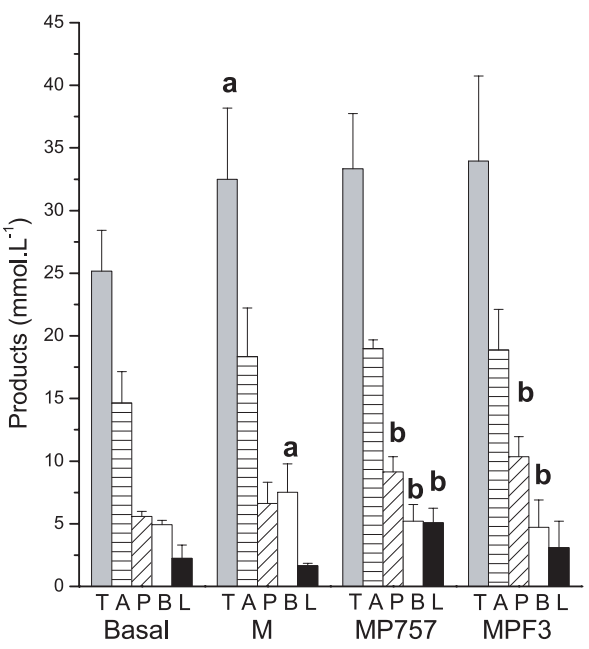

Figure 2. SCFA and lactic acid in the cecal content of mice on the 7 th day of feeding with experimental diets. Diets are indicated as follows: Basal, water control; M, non-fat milk; MP757, non-fat milk containing $P$. freudenreichii CRL757; MPF3, non-fat milk containing $P$. freudenreichii F3. Significant differences between controls $(P<0.05)$ are indicated with the character $\mathbf{a}$; significant differences between treatments and $\mathrm{M}$ group $(P<0.05)$ are indicated with the character $\mathbf{b}$. Columns: grey, total SCFA (T); horizontal lines, acetic acid (A); slant lines, propionic acid (P); white, butyric acid (B); black, lactic acid (L).

was compared with the water control sample, that was also incubated in anaerobic conditions, we observed a significant difference only in the lactic acid production.

Homogenates inoculated with the strains of $P$. acidipropionici produced more propionic acid and less butyric acid than homogenates without PAB addition. The relative amount of acetic acid was also lower, although PAB are acetic acid producers (Tab. I).

We obtained similar results in homogenates incubated with supplementation of $P$. freudenreichii (Fig. 5). However, there was a remarkable reduction in lactate concentration in accordance with the preferential consumption of lactate by $P$. freudenreichii strains. 


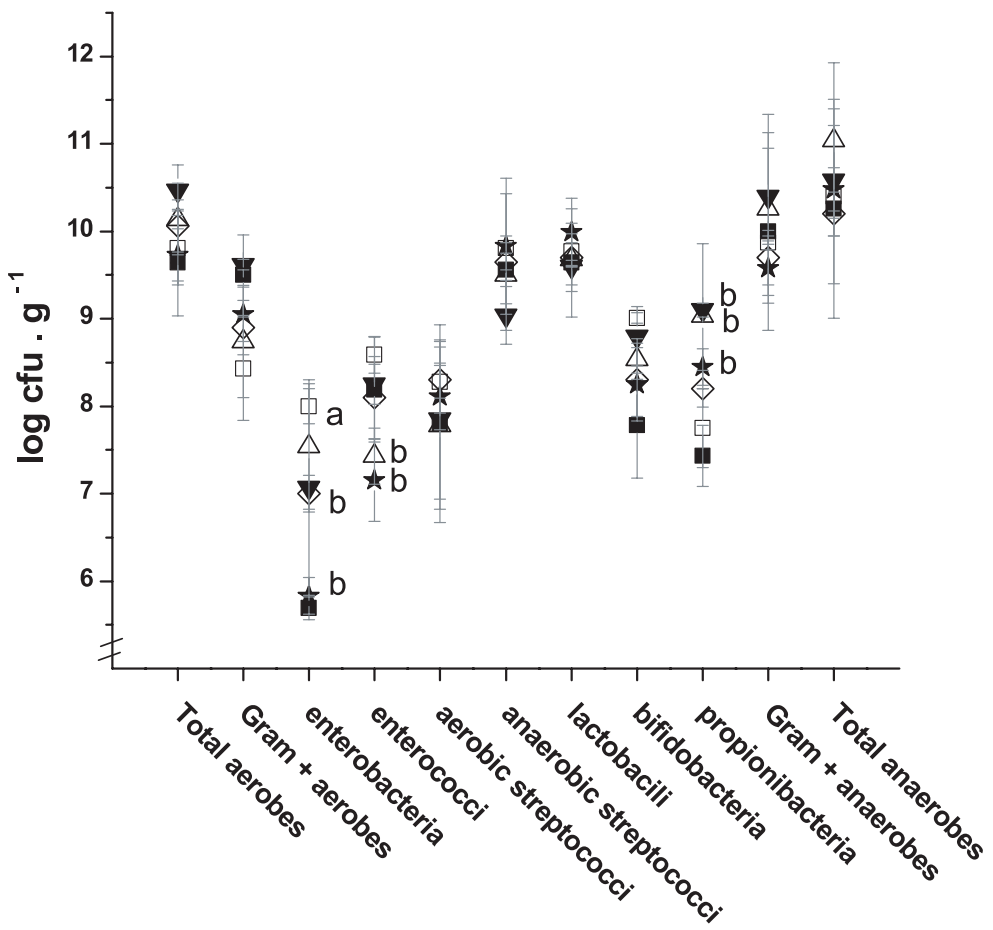

Figure 3. Bacterial counts in mice ceca on the 7th day of feeding with experimental diets. Symbols: 口, water control; $\square$, non-fat milk; $\triangle$, non-fat milk plus P. acidipropionici CRL1198; $\boldsymbol{\nabla}$, non-fat milk plus $P$. acidipropionici $\mathrm{Q} 4 ; \star \star$, non-fat milk plus $P$. freudenreichii $\mathrm{F} 3 ; \diamond$, non-fat milk plus $P$. freudenreichii CRL 757. Significant differences between water and milk controls $(P<0.05)$ are indicated with the character $\mathbf{a}$; significant differences between treatments and milk control group $(P<0.05)$ are indicated with the character $\mathbf{b}$.

The production of SCFA by $P$. acidipropionici was also evaluated in vitro under anaerobic conditions in batch cultures of mice cecal homogenates with the addition of sucrose or fructooligosaccharides (FOS). Table II shows the relative amounts of SCFA produced after incubation of these cecal homogenates.

The molar ratios of SCFA showed that in vitro fermentation of endogenous substrates led to greater production of butyric acid either in the absence (water control sample) or in the presence of Propionibacterium, compared with the basal value. However, there was more propionic acid in cecal homogenates with the dairy PAB.
Sucrose fermentation by the intestinal microflora significantly increased lactic and acetic acid concentrations in cecal homogenates at the expense of propionic and butyric acid compared with the control without carbohydrate. However, homogenates containing $P$. acidipropionici CRL 1198 had a noticeable reduction in butyric acid and an increase in propionic acid production from sucrose fermentation.

The intestinal microflora fermented FOS, producing mainly lactic acid, while the relative amount of propionic acid diminished compared with the control without carbohydrate supplementation. More acetic acid and less butyric and lactic acids, but no 


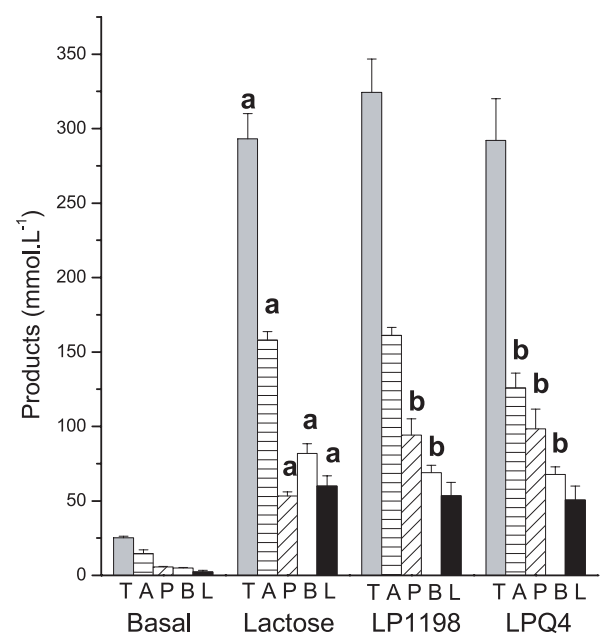

Figure 4. SCFA and lactic acid in mice cecal homogenates after lactose fermentation by different propionibacteria. Samples are indicated as follows: Basal, without lactose or bacteria; Lactose, control without bacteria; LP1198, homogenate containing lactose and P. acidipropionici CRL1198; LPQ4, homogenate containing lactose and $P$. acidipropionici Q4. Significant differences between controls $(P<0.05)$ are indicated with the character a; significant differences between test homogenates and lactose control $(P<0.05)$ are indicated with the character b. Columns: grey, total SCFA (T); horizontal lines, acetic acid (A); slant lines, propionic acid (P); white, butyric acid (B); black, lactic acid (L).

enhancement of propionic acid, were observed in the presence of propionibacteria.

\subsection{Viability and metabolic activity after cheese-making}

We also evaluated the persistence of probiotic properties of $P$. acidipropionici CRL1198 after technological processing by feeding mice with a mini-Swiss cheese elaborated with this strain of PAB. Counts in the cecal tissues and contents were made and bacterial $\beta$-galactosidase activity was determined. As shown in Table III, the number of propionibacteria belonging to the endogenous flora increased after a daily

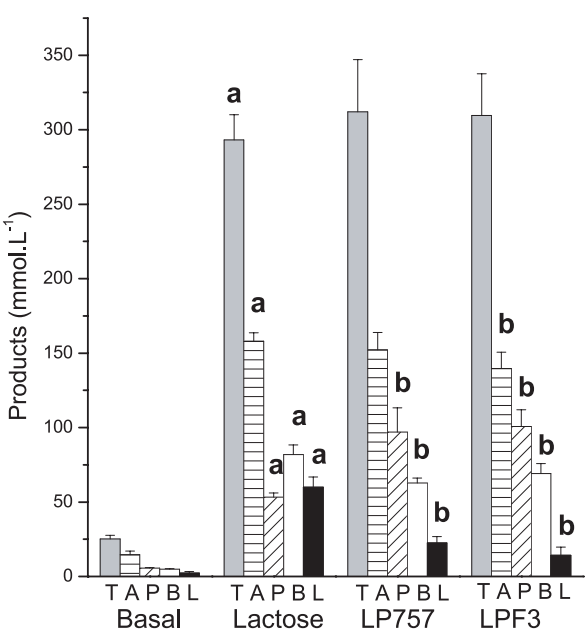

Figure 5. SCFA and lactic acid in mice cecal homogenates after lactose fermentation by different propionibacteria. Samples are indicated as follows: Basal, without lactose or bacteria; Lactose, control without bacteria; LP757, homogenate containing lactose and $P$. freudenreichii CRL757; LPF3, homogenate containing lactose and $P$. freudenreichii F3. Significant differences between controls $(P<0.05)$ are indicated with the character a; significant differences between test homogenates and lactose control $(P<0.05)$ are indicated with the character b. Columns: grey, total SCFA (T); horizontal lines, acetic acid (A); slant lines, propionic acid (P); white, butyric acid (B); black, lactic acid (L).

consumption of milk for $7 \mathrm{~d}$. Both groups of mice receiving $P$. acidipropionici CRL1198 showed high counts of propionibacteria in the ceca, which were close to the daily dose of probiotic provided to the treatment groups, although the mice were deprived of food almost $12 \mathrm{~h}$ before being sacrificed. The cecal tissue of the milk-fed control had a low number of propionibacteria that increased by almost two logs in mice receiving the probiotic bacteria delivered in either milk or cheese.

The $\beta$-galactosidase activity of the cecal contents was slightly higher in the PAB-fed groups than in the milk-fed group, but both were significantly different from the water control group. 
Table II. Relative amounts of acetic, propionic, butyric and lactic acids in cecal homogenates after sucrose or FOS fermentation ${ }^{\mathrm{a}}$.

\begin{tabular}{lcc}
\hline Sample & Ratio & Lactate \\
& A : P: B c & $(\%)^{\mathrm{d}}$ \\
\hline Basal $^{\mathrm{b}}$ & $58: 22: 20$ & 8.2 \\
Water control & $54: 20: 26^{+}$ & 5.0 \\
W + P. acidipropionici CRL1198 & $51: 25^{*}: 24^{+}$ & 4.7 \\
Sucrose & $67 *: 13^{*}: 20^{*}$ & $66.1^{*}$ \\
Sucrose + P. acidipropionici CRL1198 & $69 *: 19: 12^{*}$ & $60.0^{*}$ \\
FOS & $57: 16^{*}: 27$ & $69.0 *$ \\
FOS + P. acidipropionici CRL1198 & $76 *: 17^{*}: 7^{*}$ & $51.9 *$ \\
\hline
\end{tabular}

a Mice cecal homogenates were supplemented with sterile sucrose, FOS or the same volume of water (C). Half the volume of each sample was inoculated with $P$. acidipropionici CRL1198 $\left(10^{9} \mathrm{cfu} \cdot \mathrm{g}^{-1} \mathrm{of}\right.$ wet weight of the cecal content). The SCFA and lactate concentration were determined in all samples after incubation for $12 \mathrm{~h}$ at $37^{\circ} \mathrm{C}$ in an anaerobic atmosphere.

${ }^{\mathrm{b}}$ Homogenate without incubation.

${ }^{\mathrm{c}} \mathrm{A}$, acetate; P, propionate; B, butyrate. (Mean value of $\%$ of total SCFA). Relative amounts of each SCFA and lactate were calculated and statistically analyzed (Materials and Methods). A plus symbol in samples without carbohydrate supplementation indicates significant differences $(P<0.05)$ compared with the basal value. Asterisks indicate significant differences in cecal homogenates compared with the fermentation control without carbohydrate or bacteria supplementation (Water control).

d $\%$ of total acids.

Table III. Bacterial $\beta$-galactosidase activity and counts of propionibacteria in intestinal tissues and contents of mice fed different diets ${ }^{*}$.

\begin{tabular}{|c|c|c|c|c|c|c|}
\hline \multirow[b]{2}{*}{ Diets } & \multicolumn{4}{|c|}{$\begin{array}{l}\text { Viable counts } \\
\left(\log _{10} \mathrm{cfu} \cdot \mathrm{g}^{-1}\right)\end{array}$} & \multicolumn{2}{|c|}{$\begin{array}{l}\beta \text {-galactosidase activity } \\
\left(\mu \mathrm{mol} \cdot \mathrm{h}^{-1} \cdot \mathrm{g}^{-1}\right)\end{array}$} \\
\hline & $\begin{array}{l}\text { Small bowel } \\
\text { tissue }\end{array}$ & $\begin{array}{l}\text { Small bowel } \\
\text { content }\end{array}$ & $\begin{array}{l}\text { Cecal } \\
\text { tissue }\end{array}$ & $\begin{array}{l}\text { Cecal } \\
\text { content }\end{array}$ & $\begin{array}{l}\text { Small bowel } \\
\text { content }\end{array}$ & $\begin{array}{l}\text { Cecal } \\
\text { content }\end{array}$ \\
\hline Water & $\mathrm{nd}^{* * *}$ & $4.9 \pm 0.9$ & nd & $5.8 \pm 0.8$ & $12.6 \pm 2.8$ & $380.6 \pm 33.2$ \\
\hline Milk & nd & $5.8 \pm 0.5$ & $3.7 \pm 0.3$ & $6.4 \pm 0.3$ & $23.5 \pm 3.0^{\mathrm{a}}$ & $460.3 \pm 62.4^{\mathrm{a}}$ \\
\hline $\begin{array}{l}\text { Milk }+ \\
\text { bacteria** }^{* *}\end{array}$ & $3.6 \pm 0.5$ & $8.5 \pm 0.9^{\mathrm{a}}$ & $5.9 \pm 0.6^{\mathrm{a}}$ & $9.5 \pm 0.7^{\mathrm{a}}$ & $32.8 \pm 3.8^{b}$ & $520.9 \pm 51.5^{a}$ \\
\hline Cheese ${ }^{* *}$ & nd & $8.0 \pm 0.6^{\mathrm{a}}$ & $5.0 \pm 0.8^{\mathrm{a}}$ & $8.8 \pm 0.3^{\mathrm{a}}$ & $40.2 \pm 2.7^{c}$ & $518.6 \pm 13.8^{a}$ \\
\hline
\end{tabular}

\footnotetext{
* The different groups were fed a solid conventional diet and drank/ate water, milk, milk with propionibacteria or cheese. Viable counts of propionibacteria $\left(\log _{10} \mathrm{cfu} \cdot \mathrm{g}^{-1}\right)$ were determined in the mice intestinal tissues and contents at the end of the $7 \mathrm{~d}$ of treatments. $\beta$-galactosidase activity was determined in the small bowel and cecal contents as indicated in Materials and Methods. Results are means $\pm \operatorname{sd}(n=5)$. Different superscripts in values of the same sample indicate significant differences between treatments $(P<0.05)$.

${ }_{* *}$ Bacterial dose was adjusted to provide $10^{9}$ cells of $P$. acidipropionici CRL1198 per day. *** nd, $<10^{3} \mathrm{cfu} \cdot \mathrm{g}^{-1}$ (limit of detection).
} 


\section{DISCUSSION}

Intestinal microflora, host physiology and diet influence the stability of the gut ecosystem and health status of the host. A well-balanced microflora helps the host to avoid infections by pathogens and to digest complex nutrients. However, normal microflora is also responsible for diet-dependent harmful effects such as the potential production of toxic or carcinogenic compounds and the undesirable production of gas by carbohydrate fermentation evidenced by flatulence and abdominal pain [32].

Therefore, many efforts have been made to reduce harmful effects of the intestinal microflora by including prebiotics or probiotics in the diet. Prebiotics influence the intestinal ecosystem by stimulating the growth of specific groups of bacteria able to break them down $[8,31]$. Probiotics, in turn, may compete for substrates or break down intermediate metabolites or products of carbohydrate fermentation, resulting in a carbon flow directed to metabolic pathways that yield a lower amount of gas and a higher amount of SCFA [26, 27]. As SCFA are involved in a wide range of physiological functions, the composition of the intestinal microflora and its fermentative activity are important factors to consider for disease prevention.

Different authors have reported dietary supplementations with lactobacilli or bifidobacteria to manipulate the colonic fermentation to increase production of SCFA. In these studies, the main fermentation products were acetic and lactic acids [19, 20]. Lactate is slowly absorbed from the lumen by the colonic mucosa and leaves the intestine with the feces, contributing to losing the energy contained in the fermentable carbohydrate molecules. Therefore, dietary supplementation with $\mathrm{PAB}$ to improve colonic fermentation seems to be the best option considering that $\mathrm{PAB}$ produce acids, like propionic acid, more easily absorbed from the intestinal lumen.

In the present study, we reported changes in the type and amount of SCFA produced by the intestinal microflora depending on diet, fermentable carbohydrates and $\mathrm{PAB}$ supplementation.
In our in vivo experiments, we observed an increased number of viable bacteria in some groups fed with milk that might be due to the adaptation of the endogenous flora to more nutritive feeding containing milk proteins. We determined that lactose from milk could not reach the cecum in significant amounts after $7 \mathrm{~d}$ of feeding, because of the increase in lactase activity and microflora adaptation in the small bowel that improved dietary lactose utilization [19, 36]. Thus, endogenous substrates and protein supply had an important role in the fermentation pattern observed in the milk-fed mice, in which a higher amount of butyric acid was determined in the ceca. This might be due to the presence of different genera such as Clostridium and Eubacterium, which break down proteins into amino acids and obtain energy from amino acid fermentation, resulting in more butyric acid.

In the PAB-fed groups enterobacteria and, to a lesser extent, enterococci were inhibited, but the main SCFA producers' genera were not significantly affected. However, while propionic acid production increased in the presence of propionibacteria, the amount of lactic acid increased by diminishing butyric acid concentration, apparently to keep redox balance in the intestinal environment. This was possible because many gut anaerobes have branched fermentation pathways that allow them to conduce the carbon flow from butyric to lactic acid by adapting substrate catabolism in response to a change of environmental conditions [26]. As P. acidipropionici do not use lactic acid in the presence of higher amounts of glucose or lactose [35], there was no significant consumption of the lactate produced by the microflora. The preferential consumption of lactate by $P$. freudenreichii and the loss of $\beta$-galactosidase activity during gastrointestinal digestion due to the effect of trypsin in the pancreatic juice [39] led to a lower concentration of lactic acid, which was fermented into propionic acid in the cecal content of mice fed with this species.

In vitro studies showed similar results, but the relative amounts of acetic acid remarkably diminished. This suggested that other acetogenic bacteria were inhibited or 
that the metabolism was redirected towards branches with a lower energy production under carbon excess growth conditions [26]. Lactic acid consumption was also noticeable in homogenates containing $P$. freudenreichii as lactate diminished to values 3 to 4 times lower compared with the homogenate without propionibacteria. We conclude that this species depended on the lactic acid produced by other intestinal bacteria for growth on cecal homogenates. In contrast, the direct or sequential production of SCFA via lactic acid consumption in $P$. acidipropionici depends on the amount of lactate in homogenates, intracellular concentration of pyruvic acid and properties of its $\beta$-galactosidase enzyme [35]

We also studied sucrose fermentation in the presence of propionibacteria, as it may reach the human colon at a high concentration in the sucrose maldigestion syndrome, while we evaluated FOS fermentation, because they are frequently included in infant formulas and other foods. Sucrose fermentation by the intestinal microflora has previously been reported in rats and humans [5, 33]. Among SCFA, acetate was the acid produced in the highest concentration in sucrose diets and its relative amount was not appreciably modified with the diet or microflora composition. In contrast, the relative amount of propionic acid was higher in diets that increase the number of Bacteroides and lower in diets that improve butyric acid production [5]. In our experiments we obtained similar results, as sucrose fermentation by the intestinal microflora significantly increased lactic and acetic acid concentrations in cecal homogenates, indicating that Bifidobacterium and Lactobacillus could be favored [11, 12]. However, homogenates containing propionibacteria had a significant reduction in butyric acid and increase in propionic acid production from sucrose fermentation.

The intestinal microflora fermented FOS, producing mainly lactic acid, while the relative amount of propionic acid diminished and no improvement in the production of this acid was observed in the presence of propionibacteria. Acetic and lactic acids are the main fermentation products of FOScontaining diets, as FOS are especially effective at sustaining the growth of intestinal Bifidobacterium [20, 21]. However, butyric acid production was also increased in prolonged consumption of FOS [23] and resistant starch-diets in which bifidobacteria and lactobacilli are favored [33], although they are not butyric acid producers. Therefore, changes in the fermentation pattern were not always consistent with changes in the microflora composition, suggesting that the overall result of fermentation is more important than the number of bacteria from individual genera.

Butyric acid stimulates proliferation of normal crypt cells, but also favors differentiation and induces growth arrest and apoptosis in various tumor cell lines $[1,14,15]$. It modifies gene expression via several mechanisms, including inhibition of histone deacetylase $[2,16]$ and DNA hypermethylation [28]. Therefore, there is a great interest in ensuring the production of butyric acid in the intestinal environment.

The fermentation pathways that lead to butyric acid production are also responsible for $\mathrm{H}_{2}$ and $\mathrm{CO}_{2}$ production, involved in abdominal pain and flatulence. Moreover, they are precursors of $\mathrm{CH}_{4}$, an undesirable metabolic product in people who harbor large concentrations of methane-forming Archaea strains [27, 34]. In contrast, the fermentation pathways that lead to propionic acid, which has effects similar to those of butyric acid on the colonic mucosa [16, 17], do not produce $\mathrm{H}_{2}$ or $\mathrm{CH}_{4}$. Therefore, improvement of colonic fermentation by including dairy propionibacteria in the diet may result in a real health benefit.

Previous studies on the intestinal production of SCFA during the consumption of capsules containing a dairy propionibacteria by human volunteers showed that there were no differences in the SCFA profile measured in feces [18] related to basal values. Longer treatment periods or a diet supplemented with specific carbohydrates seems to be necessary to modify the fermentation pattern.

In our experiments, only milk supplementation and lactose fermentation were conducive to a higher production of propionic acid, either by direct or sequential consumption of substrate, in the presence of PAB. 
This supported the criterion that they should be delivered to the intestine in a dairy product.

The development of probiotic cheeses for delivery of beneficial microorganisms has some precedents $[9,10]$. Considering the low growth rate of PAB in milk and the protective effect of the cheese matrix, the latter seems to be a better option for delivering these bacteria to the intestine.

According to our results, Swiss-type cheeses containing probiotic PAB could be used to improve carbohydrate utilization in the human intestine, as they resist the technological processing of this type of cheese and keep their adhesive properties, viability and metabolic activity in the intestinal environment.

Acknowledgments: The authors wish to thank Dr M. Nuñez de Kairuz for her technical assistance with the cheese-manufacturing. This work had financial support from the Consejo Nacional de Investigaciones Científicas y Técnicas (CONICET, PIP 2802 and PEI 6100), and Consejo de Investigaciones de la Universidad Nacional de Tucumán (CIUNT, D-220), Argentina.

\section{REFERENCES}

[1] Barnard J.A., Warwick G., Butyrate rapidly induces growth inhibition and differentiation in HT-29 cells, Cell Growth Differ. 4 (1993) 495-501.

[2] Boffa L.C., Vidali G., Mann S., Allfrey V.G., Supression of histone deacetylation in vivo and in vitro by sodium butyrate, J. Biol. Chem. 253 (1978) 3364-3366.

[3] Bougé D., Roland N., Leberrier F., Arhan P., Effect of propionibacteria supplementation on fecal bifidobacteria and segmental colonic transit time in healthy human subjects, Scand. J. Gastroenterol. 34 (1999) 144-148.

[4] Bujazha M., Pérez Chaia A., Oliver G., Desarrollo de un medio de cultivo para el recuento de propionibacterias en contenido intestinal, in: V Congreso Latino-Americano de Microbiologia e Higiene de los Alimentos - VI Simposio Brasileiro des Microbiologia de los Alimentos - COMBHAL, Sao Paulo, Brasil, 22-26 November, 1998, Abstr. B 4.3:45.

[5] Cresci A., Orpianesci C., Silvi S., Mastrandrea V., Dolara P., The effect of sucrose or starch-based diets on short-chain fatty acids and faecal microflora in rats, J. Appl. Microbiol. 86 (1999) 245-250.

[6] Cummings J.H., Macfarlane G.T., The control and consequences of bacterial fermentation in the human colon, J. Appl. Bacteriol. 70 (1991) 443-459.

[7] Cummings J.H., Macfarlane G.T., Role of intestinal bacteria in nutrient metabolism, Clin. Nutr. 16 (1997) 3-11.

[8] Cummings J.H., Macfarlane G.T., Englyst H.N., Prebiotic digestion and fermentation, J. Clin. Nutr. 73 (2001) 415S-420S

[9] Daigle A., Roy D., Belanger G., Vuillemard J.C., Production of probiotic cheese (cheddar-like cheese) using enriched cream fermented by Bifidobacterium infantis, J. Dairy Sci. 82 (1999) 1081-1091.

[10] Gardiner G., Stanton C., Lynch P.B., Collins J.K., Fitzgerald G., Ross R.P., Evaluation of cheddar cheese as a food carrier for delivery of a probiotic strain to the gastrointestinal tract, J. Dairy Sci. 82 (1999) 1379-1387.

[11] Gibson G.R., Dietary modulation of the human gut microflora using the prebiotics oligofructose and inulin, J. Nutr. 129 (1999) 1438S-1441S.

[12] Gibson G.R., Roberfroid M.B., Dietary modulation of the human colonic microbiota: Introducing the concept of prebiotics, J. Nutr. 125 (1995) 1401-1412.

[13] Gibson G.R., Beatty E.B., Wang X., Cummings J.H., Selective stimulation of bifidobacteria in the human colon by oligofructose and inulin, Gastroenterology 108 (1995) 975-982.

[14] Heerdt B.G., Houston M.A., Augenlicht L.H., Potentiation by specific short-chain fatty acids of differentiation and apoptosis in human colonic carcinoma cell lines, Cancer Res. 54 (1994) 3288-3293.

[15] Heerdt B.G., Houston M.A., Augenlicht L.H., Short-chain fatty acid-iniciated cell cycle arrest and apoptosis of colonic epithelial cells is linked to mitochondrial function, Cell Growth Differ. 8 (1997) 523-532.

[16] Hinnebusch B.F., Meng S., Wu J.T., Archer S.Y., Hodin R.A., The effects of short-chain fatty acids on human colon cancer cell phenotype are associated with histone hyperacetylation, J. Nutr. 132 (2002) 1012-1017.

[17] Jan G., Belzacq A.S., Haouzi D., Rouault A., Metivier D., Kroemer G., Brenner C., Propionibacteria induce apoptosis of colorectal carcinoma cells via short-chain fatty acids acting on mitochondria, Cell Death Differ. 9 (2002) 179-188.

[18] Jan G., Leverrier P., Proudy I., Roland N., Survival and beneficial effects of propionibacteria in the human gut: in vivo and in vitro investigations, Lait 82 (2002) 131-144. 
[19] Jiang T., Savaiano D.A., In vitro lactose fermentation by human colonic bacteria is modified by Lactobacillus acidophilus supplementation, J. Nutr. 127 (1997) 1489-1495.

[20] Jiang T., Mustapha A., Savaiano D.A., Improvement of lactose digestion in humans by ingestion of unfermented milk containing Bifidobacterium longum, J. Dairy Sci. 79 (1996) 750-757.

[21] Kajiwara S., Gandhi H., Ustunol Z., Effect of honey on the growth of and acid production by human intestinal Bifidobacterium spp.: an in vitro comparison with commercial oligosaccharides and inulin, J. Food Prot. 65 (2002) 214-218.

[22] Kosikowski F., Cheese and fermented milk food, Edwards Brothers, Ann Arbor, MI, USA, 1977.

[23] Le Blay G., Michel C., Blottière H., Cherbut C., Prolonged intake of fructo-oligosaccharides induces a short-term elevation of lactic acid-producing bacteria and a persistent increase in cecal butyrate in rats, J. Nutr. 129 (1999) 2231-2235.

[24] Lee E.H., Fredrickson A.G., Tsuchiya H.M., Dynamics of mixed culture of Lactobacillus plantarum and Propionibacterium shermanii, Biotechnol. Bioeng. 18 (1976) 513-526.

[25] Macfarlane G.T., Cummings J.H., The colonic flora, fermentation and large bowel digestive function, in: Phillips S.F., Pemberton J.H., Shorter R.G. (Eds.), The large intestine: physiology, pathophysiology and disease, Raven Press Ltd., New York, USA, 1991, pp. 5192.

[26] Macfarlane S.M., Macfarlane G.T., Regulation of short-chain fatty acid production. Session: Short-chain fatty acids, Proc. Nutr. Soc. 62 (2003) 67-72.

[27] Miller T.L., Wolin M.J., Pathways of acetate, propionate and butyrate formation by the human fecal microbial flora, Appl. Environ. Microbiol. 62 (1996) 1589-1592.

[28] Parker M.I., de Haan J.B., Gevers W., DNA hypermethylation in sodium-butyrate treated WI-38 fibroblasts, J. Biol. Chem. 261 (1985) 2787-2790.

[29] Perez Chaia A., Nader de Macias M.E., Oliver G., Propionibacteria in the gut: effect on some metabolic activities of the host, Lait 75 (1995) 435-445.
[30] Perez Chaia A., Zárate G., Oliver G., Probiotic properties of propionibacteria, Lait 79 (1999) 175-185.

[31] Roberfroid M.B., Prebiotics: preferential substrates for specific germs?, Amer. J. Clin. Nutr. 73 (2001) 406S-409S.

[32] Rowland I.R., Metabolic interactions in the gut, in: Fuller R. (Ed.), Probiotics: the scientific basis, Chapman \& Hall, London, UK, 1992, pp. 29-53.

[33] Silvi S., Rumney C.J., Cresci A., Rowland I.R., Resistant starch modifies gut microflora and microbial metabolism in human floraassociated rats inoculated with faeces from Italian and UK donors, J. Appl. Microbiol. 86 (1999) 521-530.

[34] Wolin M.J., Miller T.L., Bacterial strains from human feces that reduce $\mathrm{CO}_{2}$ to acetic acid, Appl. Environ. Microbiol. 59 (1993) 3551-3556.

[35] Zárate G., Pérez Chaia A., Regulación de la actividad $\beta$-galactosidasa de Propionibacterium acidipropionici por lactosa y lactato, in: II Congreso Argentino de Microbiología de los Alimentos, Santa Fé, Argentina, 24-26 September, 2003.

[36] Zárate G., Pérez Chaia A., Contribution of dairy propionibacteria to the intestinal metabolism of lactosa, in: International Symposium on Dairy Propionibacteria and Bifidobacteria: Dairy and probiotic applications, Saint-Malo, France, 2-4 June 2004.

[37] Zárate G., Pérez Chaia A., Gonzalez S., Oliver G., Effect of bile on the $\beta$-galactosidase activity of dairy propionibacteria, Lait 80 (2000) 267-276.

[38] Zárate G., Morata de Ambrosini V., Pérez Chaia A., Gonzalez S., Adhesion of dairy propionibacteria to intestinal epithelial tissue in vitro and in vivo, J. Food Prot. 65 (2001) 534-539.

[39] Zárate G., Pérez Chaia A., Oliver G., Viability and $\beta$-galactosidase activity of dairy propionibacteria subjected to digestion by artificial gastric and intestinal fluids, J. Food Prot. 63 (2001) 1214-1221.

[40] Zárate G., Morata de Ambrosini V., Pérez Chaia A., Gonzalez S., Some factors affecting the adherence of probiotic Propionibacterium acidipropionici CRL 1198 to intestinal epithelial cells, Can. J. Microbiol. 48 (2002) 449-457. 